\title{
Determining the optimum temperature for dry extrusion of full-fat soyabeans
}

\author{
D. Palic $^{1,3 \#}$, F.K. Siebrits ${ }^{2}$ and S.E. Coetzee ${ }^{1}$ \\ ${ }^{1}$ ARC-Animal Production Institute, Private Bag X2, Irene 0062, South Africa \\ ${ }^{2}$ Tshwane University of Technology, Private Bag X680, Pretoria 0001, South Africa
}

\begin{abstract}
Full-fat soyabeans (FFSB) intended for use in monogastric nutrition need to undergo heat treatment so that present anti-nutritional factors can be inactivated. Under- or over-treatment will decrease the level of amino acids available to the animal. In this study, the slope-ratio technique was used in two trials with broilers for determining the optimum treatment temperature for soyabeans. Average daily weight gain (ADWG) and feed conversion efficiency (FCE) were used as response parameters. The optimum temperature for dry extrusion of FFSB was $144^{\circ} \mathrm{C}$ for Trial 1 and $138{ }^{\circ} \mathrm{C}$ for Trial 2. Similar temperature values were generated by both ADWG and FCE. Either one can therefore be used as response parameter for determining the optimal heat treatment conditions of FFSB for use in poultry feeding.
\end{abstract}

Keywords: Processing, heat treatment, quality control

${ }^{\#}$ Corresponding author. E-mail: dragan.palic@fins.uns.ac.rs

\section{Introduction}

Full-fat soyabeans (FFSB) contain anti-nutritional factors (ANFs) which limit their use in monogastric diets (Monari, 1996). The ANFs can be inactivated by heat treatment. However, overtreatment will damage the protein and decrease amino acid availability (Vohra \& Kratzer, 1991). There is therefore an optimum treatment temperature for each type of heat treatment, where the ANFs are sufficiently removed without damage to reactive amino acids. Lee \& Garlich (1992) suggested that heating conditions (time and temperature) in a toaster of $50 \%$ more than the optimum will not affect amino acid availability in broiler diets. Clarke \& Wiseman (2005) found that factors other than trypsin inhibitor activity also affect amino acid digestibility. The aim of this study was to find a method sensitive enough to determine the optimum treatment temperature of soyabeans processed by dry extrusion.

\section{Material and Methods}

Batterham et al. (1986) described the slope-ratio technique to determine protein quality. It is based on the principle that a protein source is fed at different sub-requirement levels so that a linear response line is obtained. A reference protein with a known availability is also fed at different subrequirement levels. Response parameters such as growth rate are then regressed against the protein intakes. The slope-ratio is calculated as the slope of the test protein response line divided by the slope of the reference protein response line.

Two in vivo trials in which soyabeans were fed to broiler chicks were conducted using the slope-ratio technique. The first trial was conducted during winter and the second one conducted the following year during summer. For both trials raw soyabeans were processed by dry extrusion at temperatures of $115^{\circ} \mathrm{C}, 125^{\circ} \mathrm{C}, 135^{\circ} \mathrm{C}, 145^{\circ} \mathrm{C}$ and $165^{\circ} \mathrm{C}$ and fed to chickens. Synthetic L-lysine was used as the reference nutrient, which was assumed to be $100 \%$ available to chickens. A total of 18 diets in triplicate were used as follows: three reference diets containing synthetic L-lysine, with inclusion levels of 5,7 and $8 \mathrm{~g} / \mathrm{kg}$ digestible lysine and 15 test diets, using five processed FFSB samples with inclusions to secure approximately the same three lysine levels. Fifty four pens were used (18 diets in three replicates) each containing eight Ross male birds (total of 432 birds in both trials). The birds received the diets from day seven to day 18 (first trial) and from day seven to day 21 (second trial). Body protein is the response parameter of choice (Siebrits et al., 1986) but it is expensive and relatively difficult to determine. Therefore, average daily weight gain (ADWG) and feed conversion efficiency (kg weight gain per kg feed consumed) (FCE) were used as response parameters for lysine intake. 


\section{Results and Discussion}

Calculated slope-ratios for both ADWG and FCE are shown in Table 1.

Table 1 Slope-ratios of average daily weight gain (ADWG) and feed conversion efficiency (FCE) as response parameters in Trial 1

\begin{tabular}{ccc}
\hline $\begin{array}{c}\text { Treatment/ } \\
\text { Temperature }\end{array}$ & $\begin{array}{c}\text { Slope-ratio } \\
\text { ADWG }\end{array}$ & $\begin{array}{c}\text { Slope-ratio } \\
\text { FCE }\end{array}$ \\
\hline Synthetic lysine & - & - \\
$115^{\circ} \mathrm{C}$ & 0.896 & 0.943 \\
$125^{\circ} \mathrm{C}$ & 1.012 & 1.022 \\
$135^{\circ} \mathrm{C}$ & 1.085 & 1.099 \\
$145^{\circ} \mathrm{C}$ & 1.108 & 1.167 \\
$165^{\circ} \mathrm{C}$ & 0.988 & 1.045 \\
\hline
\end{tabular}

Table 2 Slope-ratios of average daily weight gain (ADWG) and feed conversion efficiency (FCE) as response parameters in Trial 2

\begin{tabular}{ccc}
\hline $\begin{array}{c}\text { Treatment/ } \\
\text { Temperature }\end{array}$ & $\begin{array}{c}\text { Slope-ratio } \\
\text { ADWG }\end{array}$ & $\begin{array}{c}\text { Slope-ratio } \\
\text { FCE }\end{array}$ \\
\hline Synthetic lysine & - & - \\
$115^{\circ} \mathrm{C}$ & 1.094 & 1.297 \\
$125^{\circ} \mathrm{C}$ & 1.131 & 1.391 \\
$135^{\circ} \mathrm{C}$ & 1.225 & 1.589 \\
$145^{\circ} \mathrm{C}$ & 1.239 & 1.549 \\
$165^{\circ} \mathrm{C}$ & 0.975 & 1.137 \\
\hline
\end{tabular}

The slope-ratios were subsequently regressed against the treatment temperatures to obtain quadratic polynomial regression equations (Figures 1 and 2). The maximum values of the curves were determined by finding the point where the slope of the differential is equal to zero and were considered as the optimal temperatures for dry extrusion of full-fat soyabean for use in poultry feeding (Table 3).

The optimum temperature for dry extrusion of full-fat soyabean for use in poultry feeding was about $144{ }^{\circ} \mathrm{C}$ for Trial 1 and about $138{ }^{\circ} \mathrm{C}$ for Trial 2. This is in line with the results of Ruiz et al. (2004) who established in a trial with broilers fed extruded FFSB, that the body weight gain and feed conversion ratio were best for treatment temperatures between $126{ }^{\circ} \mathrm{C}$ and $140{ }^{\circ} \mathrm{C}$, while Palic et al. (2008) found best temperature range to be between $135{ }^{\circ} \mathrm{C}$ and $145{ }^{\circ} \mathrm{C}$. Zhang et al. (1993) established that for chickens fed FFSB, growth rate increased significantly $(\mathrm{P}<0.05)$ as extrusion temperature increased from $104{ }^{\circ} \mathrm{C}$ to $138{ }^{\circ} \mathrm{C}$. Nelson et al. (1987) stated that temperatures most commonly used commercially for extruding of raw soyabeans were approximately between $135^{\circ} \mathrm{C}$ and $140{ }^{\circ} \mathrm{C}$.

The values for optimum temperature obtained in this study $\left(144^{\circ} \mathrm{C}\right.$ in Trial 1 and $138{ }^{\circ} \mathrm{C}$ in Trial 2) are particularly close to each other when it is considered that the two trials were conducted with two different batches of soyabeans and that there are other factors than only trypsin inhibitor activity that may affect amino acid availability (Lee \& Garlich, 1992; Clarke \& Wiseman, 2005). Leeson \& Atteh (1996) extruded soyabeans at temperatures ranging from $80{ }^{\circ} \mathrm{C}$ to $140{ }^{\circ} \mathrm{C}$ and fed them to broiler chickens where they performed best on the $140{ }^{\circ} \mathrm{C}$ feed. Moisture content has an effect on the efficiency of heat treatment at a particular temperature (Zarkadas \& Wiseman, 2005). It was found that wet extrusion of soyabeans at $118{ }^{\circ} \mathrm{C}$ and $120^{\circ} \mathrm{C}$ was insufficient in terms of broiler chicken growth, while maximum growth rate was obtained with extrusion at $122{ }^{\circ} \mathrm{C}$ and $126{ }^{\circ} \mathrm{C}$ (Perilla et al., 1997). 


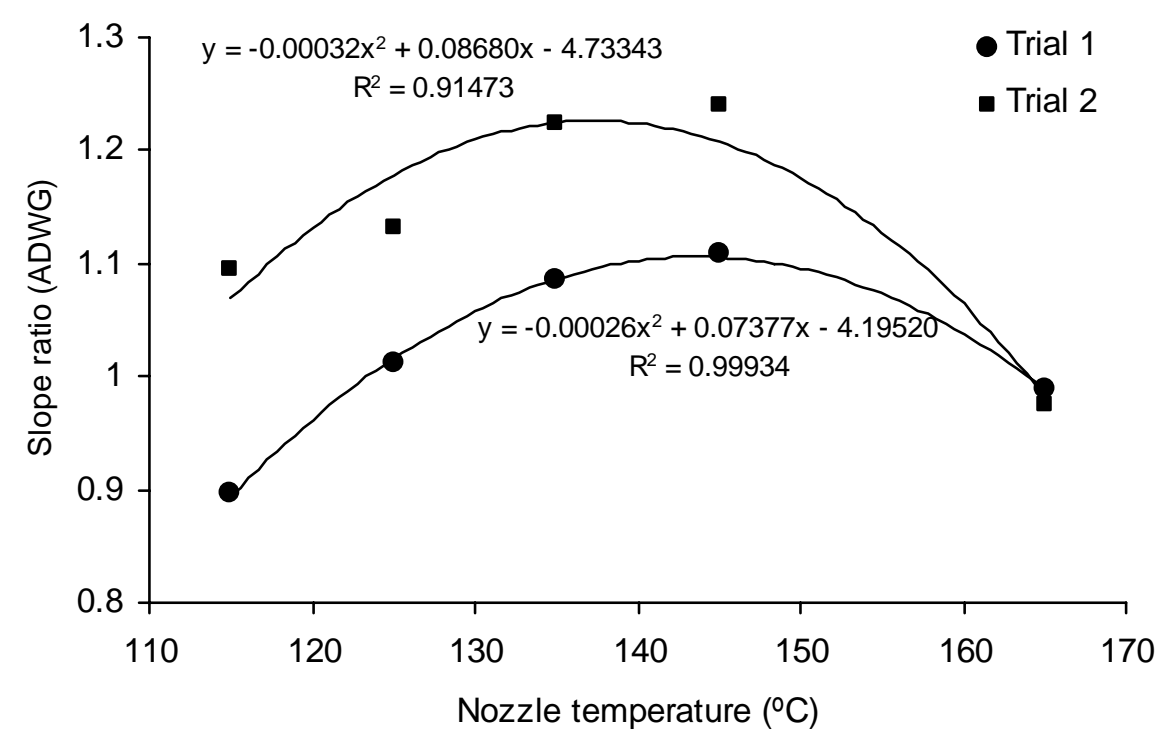

Figure 1 Equations obtained by regression of slope-ratios against treatment temperatures for average daily weight gain (ADWG) as a response parameter in Trial 1 and Trial 2.

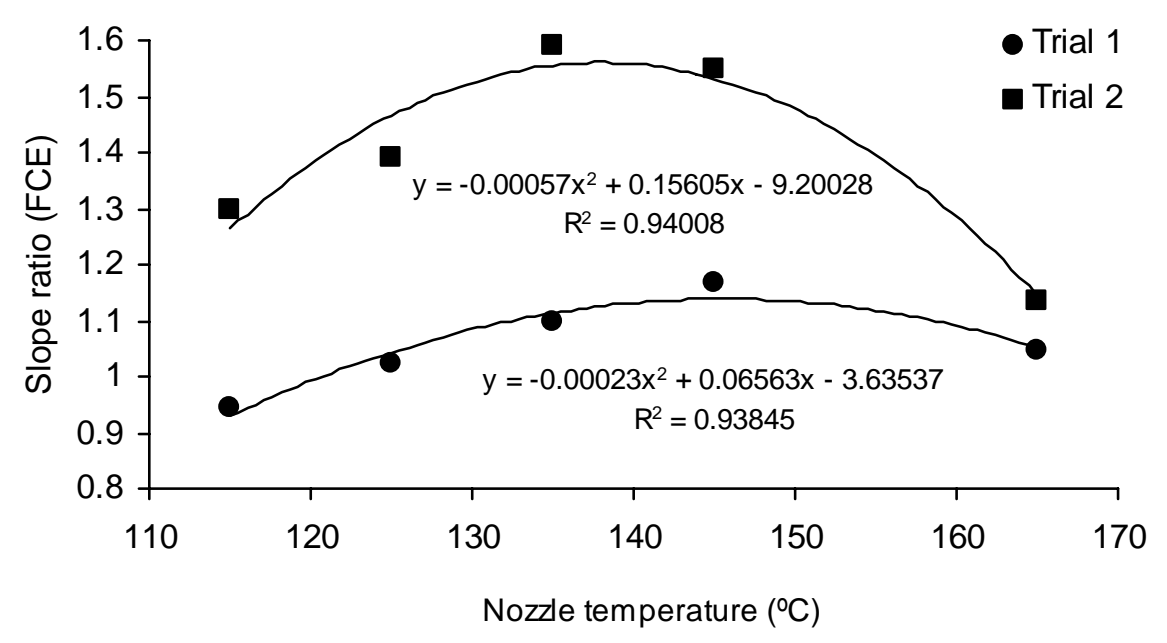

Figure 2 Equations obtained by regression of slope-ratios against treatment temperatures for feed conversion efficiency (FCE) as a response parameter in Trial 1 and Trial 2.

Table 3 Differentiated regression equations for average daily weight gain (ADWG) and feed conversion efficiency (FCE) in Trial 1 and Trial 2

\begin{tabular}{clc}
\hline Parameter & Differentiated regression equation & Maximum $\left({ }^{\circ} \mathrm{C}\right)$ \\
\hline & $\mathrm{dY} / \mathrm{dX}=-0.000551 \mathrm{X}+0.0789=0$ & 144 \\
ADWG (Trial 1) & $\mathrm{d} / \mathrm{dX}=-0.000495 \mathrm{X}+0.0718=0$ & 145 \\
FCE (Trial 1) & $\mathrm{d} / \mathrm{dX}=-0.000652 \mathrm{X}+0.0895=0$ & 137 \\
ADWG (Trial 2) & $\mathrm{dY} / \mathrm{dX}=-0.001154 \mathrm{X}+0.1590=0$ & 138 \\
FCE (Trial 2) & & \\
\hline
\end{tabular}


Although the slope-ratios did not necessarily differ significantly around the optimum point, the methodology used yielded a clear reference point. Further work needs to be done to identify the critical cut-off points where treatment conditions are sub-optimal.

\section{Conclusion}

Similar optimum temperature values were found based both on ADWG and FCE. Either one can therefore be used as response parameter for determining the optimal heat treatment conditions of full-fat soyabean for use in poultry diets.

\section{Acknowledgement}

This study was funded by the Protein Research Foundation of South Africa.

\section{References}

Batterham, E.S., Lowe, R.F. \& Darnell, R.E., 1986. Availability of lysine in meat meal, meat and bone meal and blood meal as determined by the slope-ratio assay with growing pigs, rats and chicks and by chemical techniques. Br. J. Nutr. 55, 427-440.

Clarke, E. \& Wiseman, J., 2005. Effects of variability in trypsin inhibitor content of soya bean meals on true and apparent ileal digestibility of amino acids and pancreas size in broiler chicks. Anim. Feed Sci. Technol. 121, 125-138.

Lee, H. \& Garlich J.D., 1992. Effect of overcooked soybean meal on chicken performance and amino acid availability. Poultr. Sci. 71(3), 499-508.

Leeson, S. \& Atteh, J.O., 1996. Response of broiler chicks to dietary full-fat soybeans extruded at different temperatures prior to or after grinding. Anim. Feed Sci. Technol. 57 (3), 239-245.

Monari, S., 1996. Fullfat Soya Handbook, American Soybean Association, Brussels, Belgium.

Nelson, A.I., Wijeratne, W.B., Weh, S.W., Wei, T.M. \& Wei, L.S., 1987. Dry extrusion as an aid to mechanical expelling of oil from soybeans. J. Am. Oil Chem. Soc., 64, 1341-1347.

Palic, D., Levic, J., Sredanovic, S. \& Djuragic, O., 2008. Quality control of full-fat soybeans using urease activity: critical assessment of the method. Acta Periodica Technologica, 39, 49-53.

Perilla, N.S, Cruz, P., De Belalcazar, F. \& Diaz, G.J., 1997. Effect of temperature of wet extrusion on the nutritional value of full-fat soyabeans for broiler chickens. Br. Poult. Sci. 38, 412-416.

Ruiz, N., De Belalcazar, F. \& Diaz, G.J., 2004. Quality control parameters for commercial full-fat soybeans processed by two different methods and fed to broilers. J. Appl. Poult. Res., 13, 443450.

Siebrits, F.K., Esterhuyse, C.D. \& Kemm, E.H., 1986. The relative nutritive value of lucerne leave protein concentrate (LPC) coagulated by means of steam or hot water. S. Afr. J. Anim. Sci. $16,143-145$.

Vohra, P. \& Kratzer, F.H., 1991. Evaluation of soybean meal determines adequacy of heat treatment. Feedstuffs, February 25.

Zarkadas, L.N. \& Wiseman, J., 2005. Influence of processing of full fat soya beans included in diets for piglets. I. Performance. Anim. Feed Sci. Technol. 118, 109-119.

Zhang, Y., Parsons, C.M., Weingartner, K.E., Wijeratne, W.B., 1993. Effect of extrusion and expelling on the nutritional quality of conventional and Kunitz trypsin inhibitor-free soybeans. Poult. Sci. 72, 2299-2308. 